\title{
Studi Numerik Perbandingan Kinerja dan Medan Aliran Turbin Vortex Gravitasi dengan Tipe Sudu Lengkung Backward dan Forward
}

\author{
Didit Setyo Pamuji ${ }^{*}$, Harry Laksono Nugroho ${ }^{2}$, Daru Sugati ${ }^{1}$ \\ ${ }^{1}$ Program Studi Teknik Mesin, Fakultas Teknologi Industri, Institut Teknologi Nasional Yogyakarta \\ Jl. Babarsari, Caturtunggal, Depok, Sleman, Daerah Istimewa Yogyakarta 55281 \\ ${ }^{2}$ Departemen Teknik Mesin, Sekolah Vokasi, Universitas Gadjah Mada \\ Jl. Yacaranda Sekip Unit IV Yogyakarta 55281 \\ *E-mail: didit@itny.ac.id
}

Diterima: 19-11-2020; Direvisi: 01-04-2021; Dipublikasi: 27-04-2021

\begin{abstract}
Abstrak
Interaksi sudu-sudu turbin dengan aliran pusaran pada pembangkit daya mikrohidro berbasis vortex gravitasi sampai dengan saat ini masih belum terklarifikasi dengan jelas, oleh karena itu simulasi numerik menjadi alat bantu untuk dapat menghasilkan visualisasi aliran yang membantu analisis kinerja hasil eksperimen. Penelitian ini bertujuan untuk membandingkan kinerja pembangkit daya aliran vortex gravitasi menggunakan basin conical dengan desain sudu backward lengkung dan forward lengkung menggunakan pendekatan simulasi numerik. Simulasi diawali dengan memvalidasi hasil kinerja torsi dan visualisasi aliran penelitian eksperimen yang dilakukan peneliti sebelumnya, kemudian pengaturan simulasi tersebut digunakan untuk membandingkan kinerja desain turbin sudu backward lengkung dan forward lengkung dengan variasi kecepatan rotasi turbin 80, 120, 160, dan 180 rpm. Hasil simulasi menunjukkan kinerja sudu backward lengkung lebih baik daripada sudu forward lengkung, dengan daya tertinggi yang dibangkitkan sebesar 2,34 W dan 1,51 W secara berturut-turut pada putaran $120 \mathrm{rpm}$ yang didukung melalui visualisasi aliran permukaan bebas dan kontur tekanan statis pada permukaan sudu.
\end{abstract}

Kata kunci: mikrohidro; sudu backward; sudu forward; vortex

\begin{abstract}
The interaction of turbine blades with vortex flow in micro-hydro power plants based on gravity vortex is still not clearly clarified, therefore numerical simulation is a tool to produce flow visualization that helps analyze the performance of experimental results. This study aims to compare the performance of a gravity vortex flow power generator using a conical basin with a inclined backward and inclined forward blade design using a numerical simulation approach. The simulation begins by validating the results of torque performance and visualizing the flow of experimental research conducted by previous researchers, then the simulation settings are used to compare the performance of the inclined backward and inclined forward blade turbine designs with variations in turbine rotation speed of 80,120, 160 and $180 \mathrm{rpm}$. The simulation results show that the performance of the curved backward blade is better than the forward curved blade, with the highest power generated of $2.34 \mathrm{~W}$ and $1.51 \mathrm{~W}$ respectively at $120 \mathrm{rpm}$ which is supported through visualization of free surface flow and static pressure contours on the blade surface.
\end{abstract}

Keywords: micro-hydro; backward blade; forward blade; vortex

\section{Pendahuluan}

Energi air merupakan salah satu jenis energi terbarukan termurah, paling banyak tersedia, dan paling efisien di antara sumber energi terbarukan yang lain [1]. Ekstraksi energi mekanik dari aliran air berupa sungai maupun saluran irigasi dengan beda ketinggian yang sangat rendah (very low head) dipertimbangkan sebagai salah satu solusi untuk keperluan pemenuhan kebutuhan listrik di daerah terpencil, yang masih terkendala masalah keekonomisan pembanguan jaringan listrik baru, rendahnya konsumsi listrik dan faktor pembebanan [2] serta mengurangi dampak negatif pembangunan bendungan [3].

Salah satu jenis pembangkit listrik mini/microhydro yang sedang dikembangkan untuk pemanfaatan energi air dengan head yang sangat rendah adalah dengan menggunakan gravitational water vortex. Penelitian tentang free vortex turbine mampu menghasilkan efisiensi mekanis maksimal sebesar 35,92 \%, yang mana jauh lebih tinggi dari pada kincir 
air konvensional yang hanya menghasilkan efisiensi mekanis maksimal 13,69\% [4]. Gravitational Water Vortex Power Plant (GWVPP) merupakan salah satu jenis teknologi energi terbarukan menggunakan sumber energi air dan dikategorikan sebagai mini-mikrohidro, karena pembangkitan daya yang pernah dilaporkan tidak melebihi $100 \mathrm{~kW}$ [5]. Pada pembangkit ini, air awalnya dialirkan pada sebuah saluran /kanal buatan yang selanjutnya mengalir masuk secara tangensial menuju circular basin sehingga terbentuk pusaran aliran alami atau free vortex. Pembangkit ini hanya memerlukan head yang rendah $(0,5-1 \mathrm{~m})$, sehingga dalam proses konversi energinya bukan mendasarkan pada energi karena perbedaan tekanan (pressure difference), melainkan energi karena peruabahan dinamika gaya (dynamic force) yang dibangkitkan dari vortex dikonversi menjadi energi mekanik poros turbin [6].

Penelitian terdahulu menunjukkan terdapat beberapa faktor yang memengaruhi kinerja dari free water vortex turbine seperti desain vortex pool, konfigurasi dan material turbin, serta perubahan parameter debit aliran [7]. Hasil penelitian [7] menyatakan bahwa efisiensi pembangkit meningkat seiring meningkatnya jumlah sudu turbin (dari 2 menjadi 4), namun hasil tersebut berkebalikan dengan temuan yang menyatakan bahwa efisiensi pembangkit justru menurun ketika jumlah sudu turbin ditambah [8]. Lebih lanjut dari sisi material turbin, material aluminium menghasilkan efisiensi daya yang lebih tinggi dari pada turbin yang menggunakan material besi [9]. Kecepatan rotasi yang dihasilkan turbin sebanding dengan aliran vortex yang dibangkitkan dan ketinggian vortex memengaruhi efisiensi pembangkitan dayanya [10]. Adapun penempatan posisi turbin akan menghasilkan daya optimum saat dekat dengan outlet [8]. Dengan menggunakan metode simulasi numeris, diperoleh data bahwa bentuk basin conical menghasilkan kinerja daya keluaran turbin yang lebih tinggi dibandingkan dengan basin silinder dengan posisi penempatan turbin yang optimal pada $65 \%$ sampai dengan $75 \%$ dari level permukaan air pada basin conical [11]. Selanjutnya dibuat uji eksperimen untuk memverifikasi hasil kinerja basin conical tersebut dan diperoleh efisiensi maksimal turbin dengan menggunakan basin conical mencapai 36,84\%. Penelitian eksperimen menggunakan basin conical dan multi-stage turbin juga dilakukan oleh [12], dan diperoleh hasil bahwa penggunaan multi-stage turbin menghasilkan kinerja (torsi dan daya) yang lebih tinggi dari single-stage turbin yang diuji.

Desain turbin yang melibatkan free water surface cukup rumit dilakukan dan pola aliran yang terbentuk untuk jenis turbin yang berbeda belum terklarifikasi secara menyeluruh. Visualisasi dengan simulasi numeris memiliki peran signifikan untuk dapat mengungkap fenomena aliran yang tejadi saat interaksi aliran vortex dengan sudu-sudu turbin. Simulasi dengan menggunakan metode volume of fluid pada basin silinder dan turbin jenis cross flow sudu backward lengkung telah dilakukan oleh [13], dan diperoleh hasil kinerja torsi, daya, dan efisiensi yang bersesuaian atau valid dengan hasil eksperimen. Penelitian ini akan difokuskan untuk mengkaji lebih dalam perbedaan tipe sudu backward lengkung dan forward lengkung pada turbin vortex gravitasi jenis cross flow untuk dibandingkan kinerja torsi, daya, serta medan aliran yang terbentuk pada basin dan permukaan sudu-sudunya dengan memvariasikan kecepatan putaran turbin.

\section{Material dan metodologi}

Objek penelitian awalnya mengacu pada model jenis turbin dan parameter aliran yang dilakukan oleh [13], kemudian dimodifikasi bentuk basinnya menjadi berbentuk conical sebagaimana ditampilkan pada Gambar 1. Model jenis turbin yang digunakan mengacu parameter desain sudu backward lengkung yang dengan karakteristik yang ditunjukkan pada Gambar 2 dan keterangan dimensinya pada Tabel 1. 

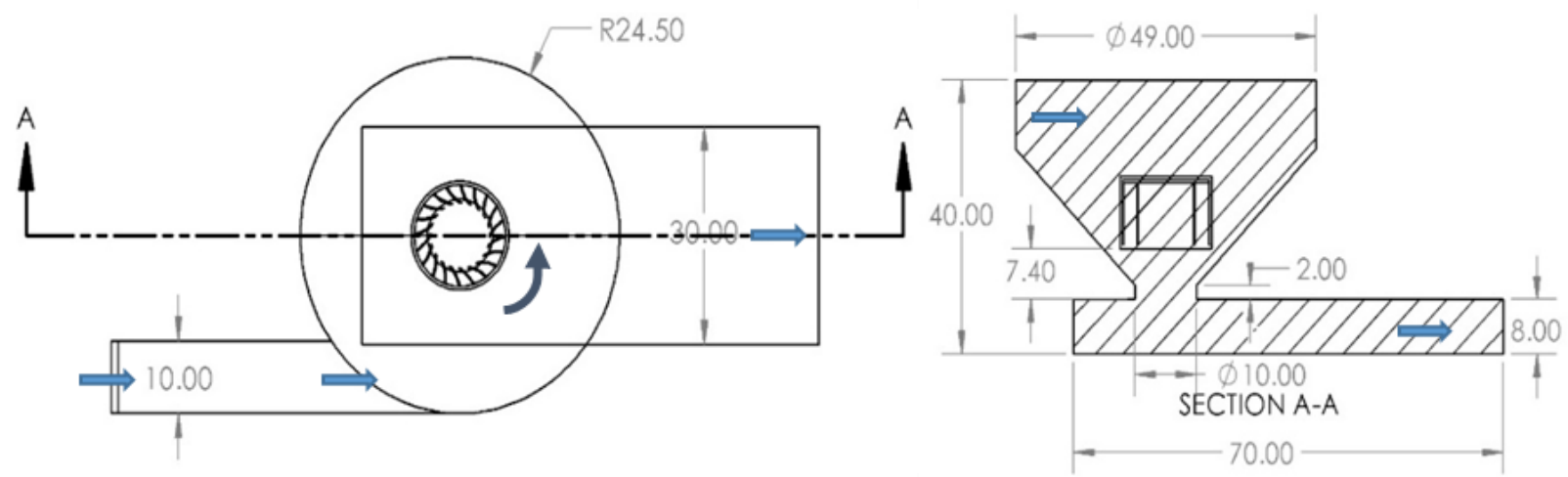

Gambar 1. Model basin conical pada penelitian ini, dalam satuan $\mathrm{cm}$

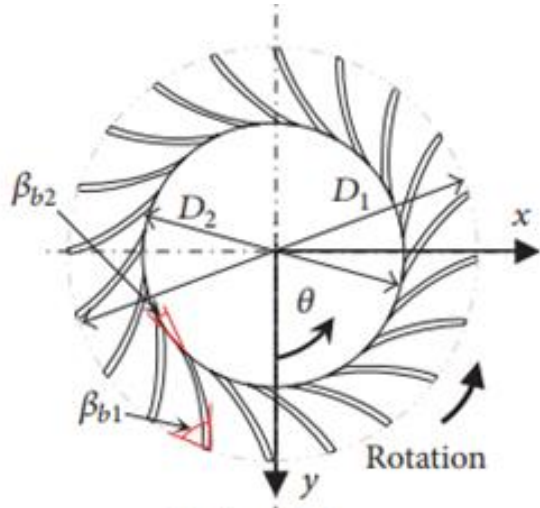

Section:B-B

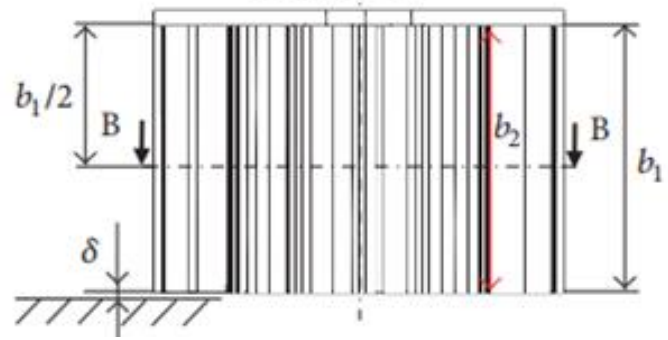

Gambar 2. Parameter desain sudu backward lengkung yang dijadikan acuan [13]

Tabel 1. Keterangan parameter desain sudu

\begin{tabular}{cc}
\hline Parameter & Nilai \\
\hline Diameter luar, $D_{1}$ & $14 \mathrm{~cm}$ \\
Diameter dalam, $D_{2}$ & $9,1 \mathrm{~cm}$ \\
Lebar sudu inlet, $b_{1}$ & $0,91 \mathrm{~cm}$ \\
Lebar sudu outlet, $b_{2}$ & $0,91 \mathrm{~cm}$ \\
Sudut inlet, $\beta_{b 1}$ & $71,9^{\circ}$ \\
Sudut outlet, $\beta_{b 2}$ & $19,0^{\circ}$ \\
Jumlah sudu, $Z$ & $20 \mathrm{buah}$ \\
\hline
\end{tabular}

Selanjutnya, tipe sudu backward lengkung divariasikan menjadi berbentuk sudu forward lengkung yang akan dibandingkan kinerjanya, desain sesuai Gambar 3. Proses validasi simulasi terlebih dahulu dilakukan dengan cara mensimulasikan ulang sesuai desain geometri dan paramter yang digunakan pada penelitian [13], setelah hasil yang diperoleh tervalidasi, pengaturan simulasi yang sama digunakan untuk basin conical dengan tipe sudu backward lengkung dan forward lengkung. Perbandingan desain geomteri basin silinder acuan dan modifikasi basin conical pada penelitian 
Didit Setyo Pamuji dkk /Jurnal Rekayasa Mesin

p-ISSN: 1411-6863, e-ISSN: 2540-7678

Vol.16|No.1|48-55|April|2021

ini ditunjukkan pada Gambar 4. Adapun tampilan perbandingan hasil meshing yang dibuat pada basin silender dan basin conical ditampilkan pada Gambar 5, sedangkan hasil meshing pada permukaan sudu ditampilkan pada Gambar 6 (a).
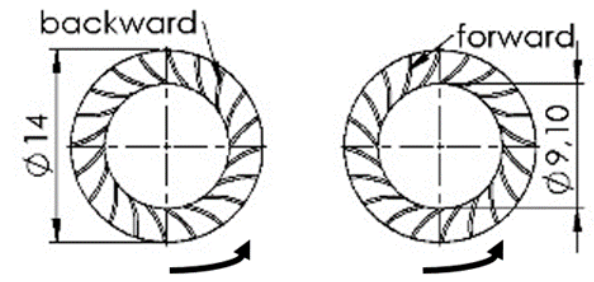

Gambar 3. Desain sudu backward lengkung dan forward lengkung

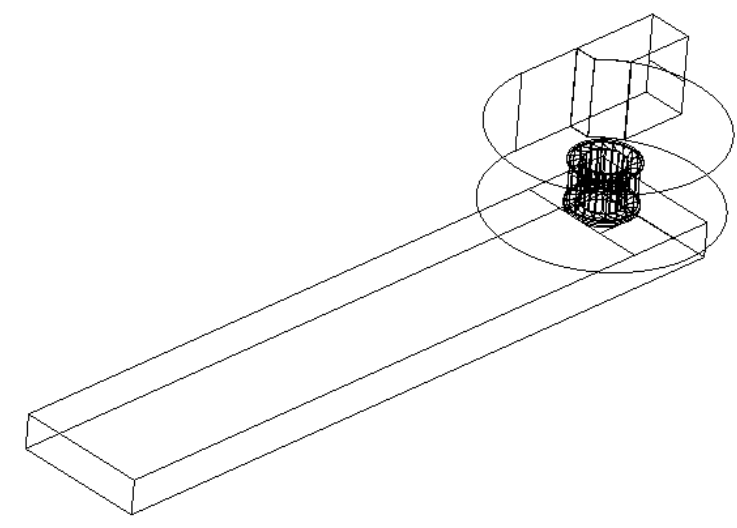

(a)

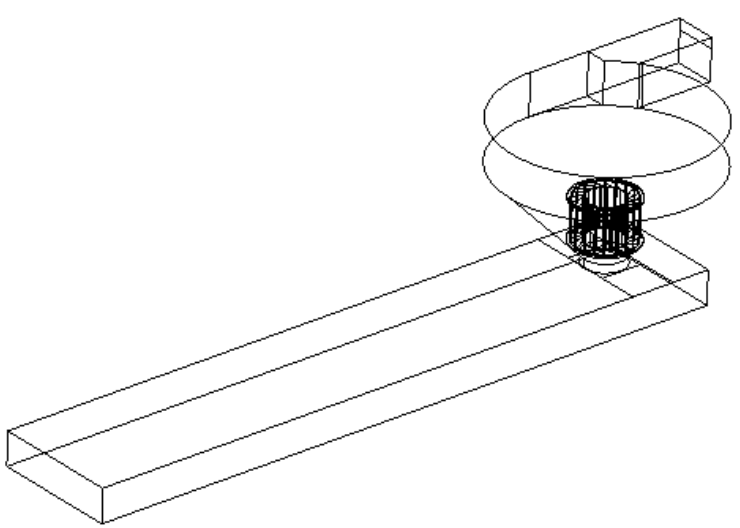

(b)

Gambar 4. (a) Geometri basin silinder [13], dan (b) modifikasi basin conical penelitian ini

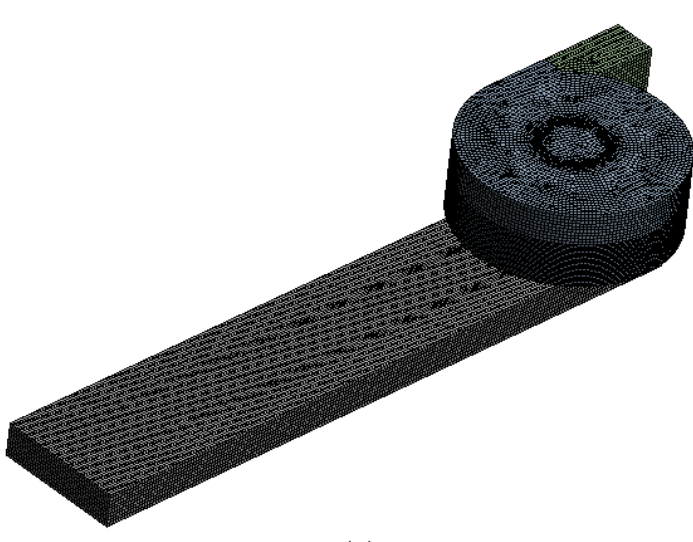

(a)

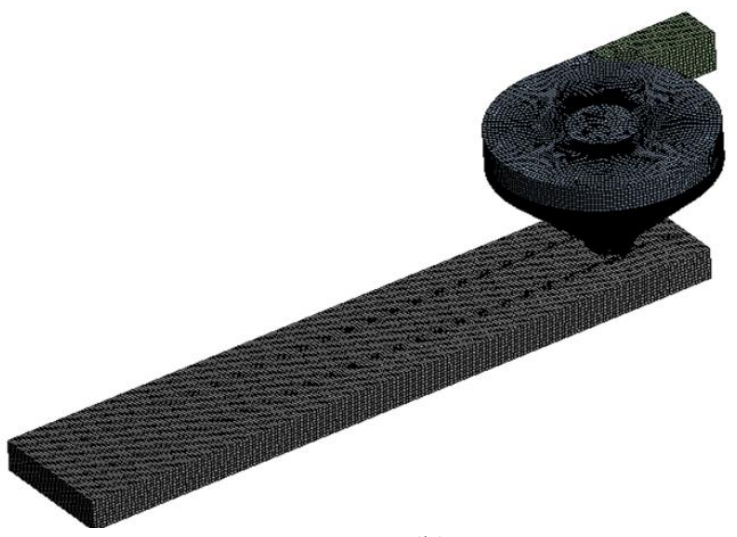

(b)

Gambar 5. (a) meshing geometri basin silinder, dan (b) meshing geometri basin conical

Analisis numerik dilakukan dengan simulasi berbasis analisis finite volume dengan metode volume of fluid (VOF) dan model turbulensi k- $\Omega$, SST menggunakan perangkat lunak ANSYS fluent [14]. Adapun parameter kondisi batas (boundary condition) yang digunakan ditampilkan pada Gambar 6 (b). Pada simulasi yang dilakukan, akan diperoleh data berupa torsi yang bersesuaian dengan input kecepatan putar yang divariasikan yaitu 80 rpm, 120 rpm, 160 rpm, dan 180 rpm. Selanjutnya, daya mekanik yang dihasilkan dihitung menggunakan Pers. (1).

$$
P=\frac{2 \pi n T}{60}
$$




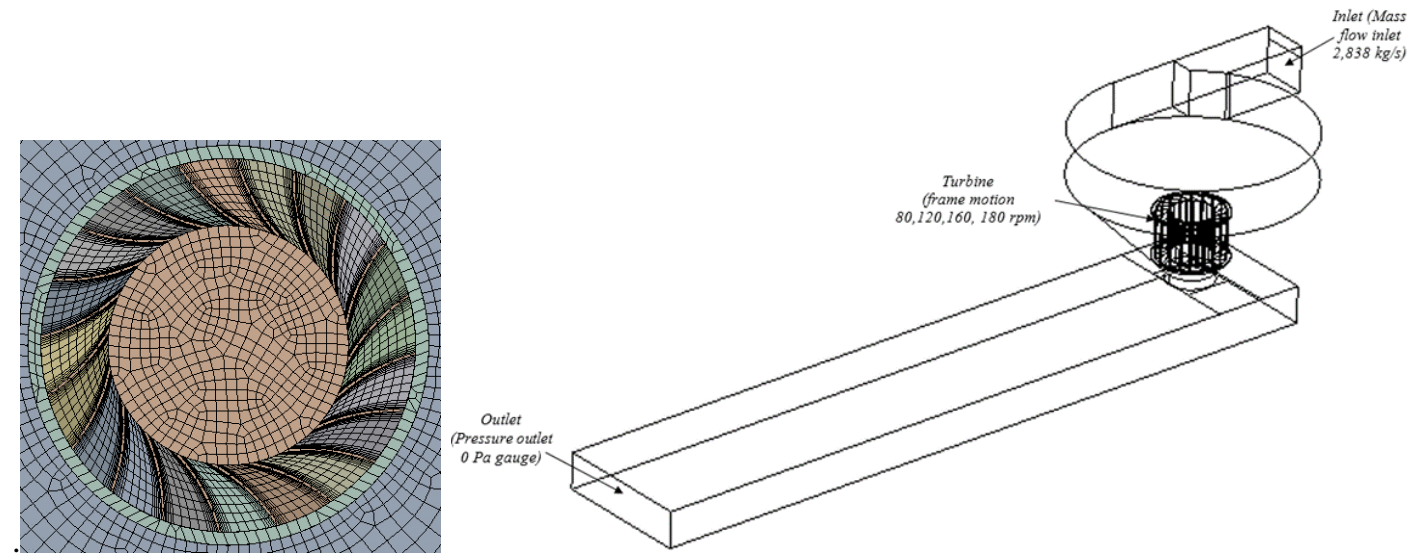

(a)

(b)

Gambar 6. (a) Meshing pada permukaan sudu dan (b) kondisi batas

\section{Hasil dan pembahasan}

\subsection{Validasi Simulasi}

Validasi dilakukan dengan membandingkan hasil simulasi penelitain ini pada kecepatan putar $122 \mathrm{rpm}$ untuk geometri basin silinder dengan hasil eksperimen dan simulasi penelitian [13]. Hasil simulasi pada penelitian ini menunjukkan nilai torsi yang diperoleh sebesar 0,1364 Nm, yang mana mendekati hasil eksperimen dan simulasi yang dilakukan oleh peneliti sebelumnya berkisar $\sim 0,13 \mathrm{Nm}$ pada kecepatan putar turbin $122 \mathrm{rpm}$. Adapun perbandingan visualisasi aliran pada permukaan bebas menggunakan isosurface fraksi volume air antara penelitian ini dengan penelitian sebelumnya, diperlihatkan pada Gambar 8. Pada visualisasi yang dihasilkan penelitian ini, terlihat permukaan bebas membentuk pusaran vortex pada basin silinder yang mana pada bagian sumbu imajiner pusaran terisi udara sedangkan permukaan air disampingnya naik. Visualisasi yang dihasilkan penelitian ini juga selaras dengan visualisasi yang dihasilkan oleh eksperimen dan simulasi pada penelitian sebelumnya. Setelah hasil simulasi pada basin silinder tervalidasi, proses pengaturan yang sama diterapkan pada simulasi menggunakan basin conical baik pada turbin sudu backward lengkung maupun forward lengkung.

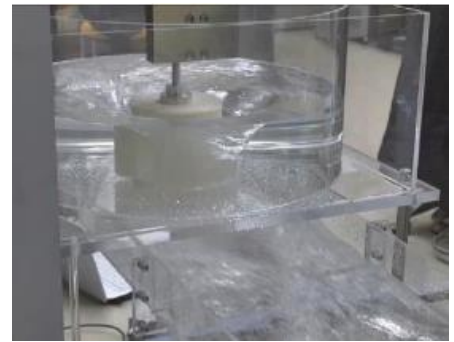

(a)

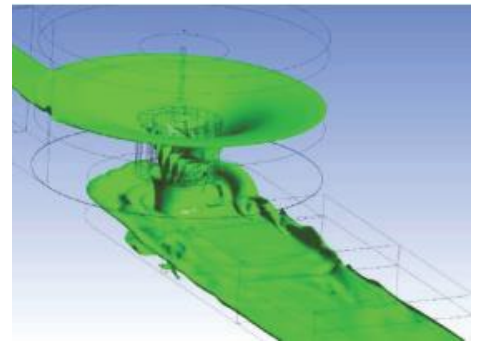

(b)

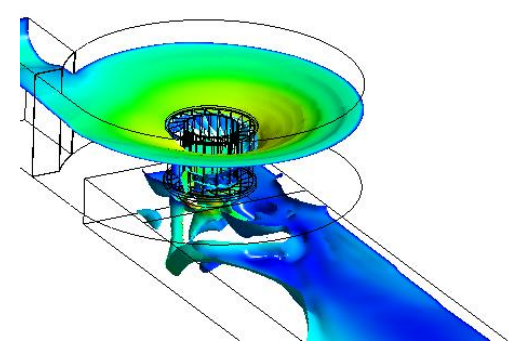

(c)

Gambar 8. (a) visualisasi aliran eksperimen [13], (b) visualisasi aliran simulasi [13], (c) visualisasi aliran pada penelitian ini.

\subsection{Perbandingan Kinerja Sudu Turbin Backward Lengkung dan Forward Lengkung}

Perbandingan nilai torsi dan daya yang dihasilkan sudu turbin backward lengkung dan forward lengkung dengan beberapa variasi kecepatan putar turbinnya ditampilkan pada Gambar 9. Berdasarkan grafik tersebut, terobservasi bahwa pada semua variasi kecepatan putar sudu, nilai torsi yang dibangkitkan dan daya mekanik yang dihasilkan oleh turbin dengan sudu backward lengkung lebih tinggi dari pada sudu forward lengkung. Dari data torsi terhadap rpm, terlihat torsi yang semakin menurun seiring bertambahnya rpm. Hal ini terjadi karena berkurangnya gaya reaksi akibat berkurangnya 
perbedaan kecepatan antara kecepatan rotasi air dengan rotasi turbin. Nilai torsi tertinggi dibangkitkan saat kecepatan putar terendah atau sekitar $80 \mathrm{rpm}$, namun karena daya merupakan perkalian antara torsi dan kecepatan putar, sebagaimana pada Persamaan (1), daya mekanik optimal yang dibangkitkan terjadi pada kecepatan putar sekitar 120 rpm, baik pada sudu turbin backward lengkung $(2,34 \mathrm{~W})$ maupun forward lengkung $(1,51 \mathrm{~W})$.

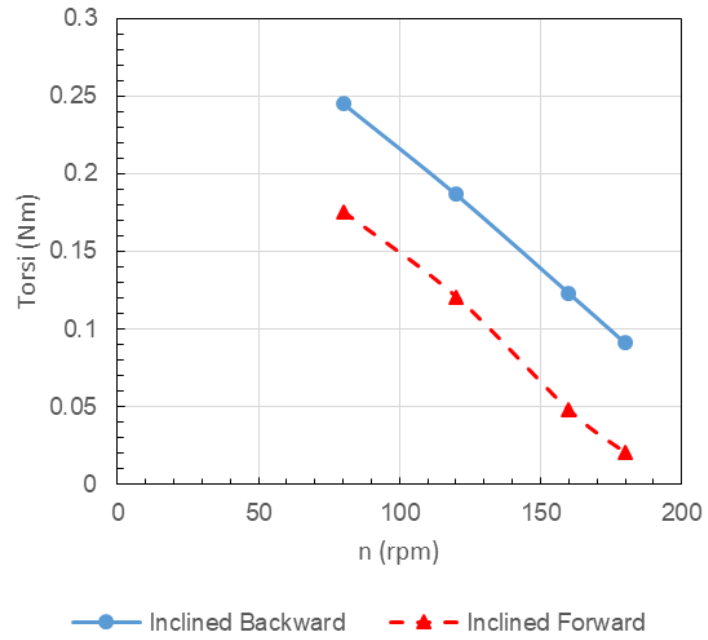

(a)

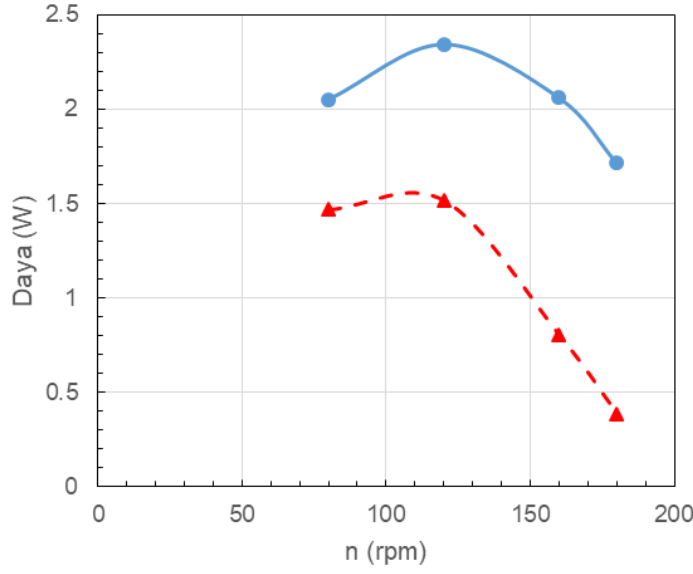

$\longrightarrow$ - Inclined Backward _ $\mathbf{A}$ - Inclined Forward

(b)

Gambar 9. (a) nilai torsi yang dibangkitkan, (b) daya mekanik yang dihasilkan

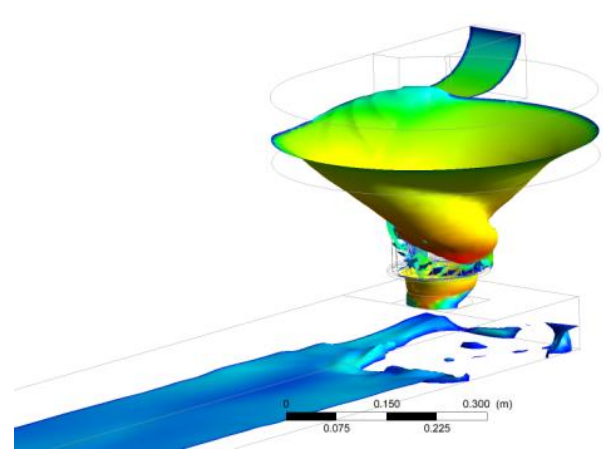

(a)

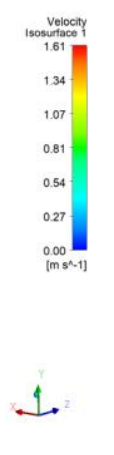

Gambar 10. (a) Visualisasi permukaan bebas sudu backward lengkung dan(b) Visualisasi permukaan bebas sudu forward lengkung

Perbandingan visualisasi permukaan bebas aliran vortex masing-masing sudu backward lengkung dan forward lengkung pada kecepatan putar optimalnya (120 rpm) diperlihatkan pada Gambar 10. Visualisasi tersebut didapatkan dengan mengatur isosurface antara air dan udara dengan nilai fraksi volume 0,9 dan menambahkan variabel kecepatan sehingga permukaan bebas atau aliran memiliki gradasi warna berdasarkan kecepatannya. Warna merah menunjukkan kecepatan paling besar, mencapai 1,61 m/s, sedangkan warna biru tua menunjukan kecepatan terendahnya, $0 \mathrm{~m} / \mathrm{s}$. Pada daerah dekat dengan dinding saluran/basin, permukaan air terlihat berwarna biru, yang menandakan kecepatannya $0 \mathrm{~m} / \mathrm{s}$ sebagaimana pada teori aliran fluida yang cenderung diam saat dekat dengan dinding yang tetap. Pada pusaran aliran / vortex untuk kedua tipe turbin, gradasi warna terjadi dari warna hijau menuju kuning orange, yang menandakan pada permukaan bebas aliran vortex terjadi penambahan kecepatan. Sebagaimana penelitian [10], bahwa kecepatan rotasi yang dihasilkan turbin sebanding dengan aliran vortex yang dibangkitkan dan ketinggian vortex memengaruhi efisiensi pembangkitan dayanya, terobservasi bahwa interaksi vortex dengan sudu backward lengkung membangkitkan kecepatan 
aliran yang lebih tinggi dari pada interaksi vortex dengan sudu forward lengkung, sebagaimana diperlihatkan pada interaksi vortex dengan sudu backward lengkung menghasilkan gradasi warna yang lebih merah.

Jenis turbin yang digunakan pada penelitian ini termasuk jenis turbin reaction yang didesain berdasarkan persamaan euler turbomachine pada sisi inlet dan outletnya. Pada jenis turbin reaction, terjadi perpindahan momentum antara aliran vortex dengan sudu-sudu turbin, sedemikian sehingga terjadi penurunan tekanan (pressure drop). Tekanan yang tertinggi terletak pada sisi inlet dan tekanan terendahnya terjadi pada sisi outlet [15]. Gambar 11 menunjukkan kontur tekanan statis pada permukaan sudu backward lengkung dan sudu forward lengkung. Baik pada sudu backward lengkung maupun forward lengkung dapat teramati bahwa tekanan tertinggi terletak pada sisi inlet di bagian paling bawah sudu, yang menunjukkan bahwa transfer momentum dari aliran vortex menuju permukaan sudu terjadi paling besar pada sisi paling bawah karena kecepatan aliran vortex juga paling tinggi berada pada sisi dekat lubang pembuangan. Jika dilihat pada sisi inlet dan outlet sudu, teramati pada sudu backward lengkung mengalami pressure drop yang lebih tinggi daripada yang terjadi pada sudu forward lengkung. Hal tersebut menunjukkan bahwa pada kecepatan putar turbin yang sama (120 rpm) transfer momentum lebih besar terjadi pada sudu dengan bentuk backward lengkung daripada sudu forward lengkung, sehingga kontur tekanan ini dapat mendukung nilai torsi yang dibangkitkan sudu backward lengkung lebih tinggi daripada yang dibangkitkan pada sudu forward lengkung.
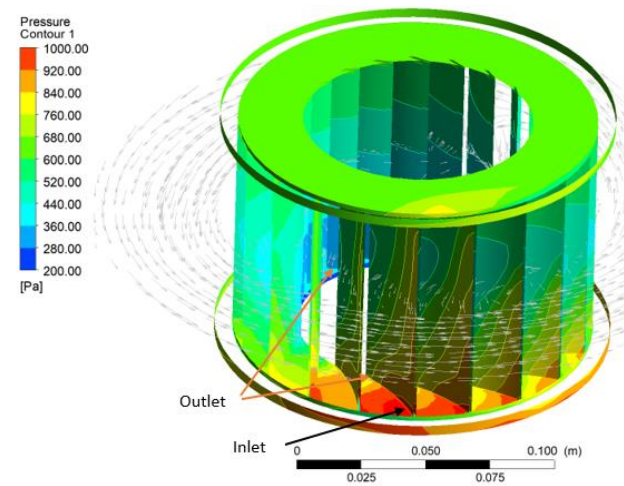

(a)
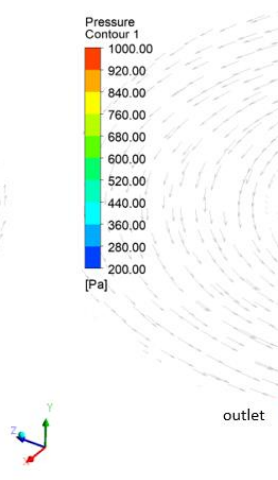

(b)

Gambar 11. (a) Kontur tekanan statis pada permukaan sudu backward lengkung, (b) Kontur tekanan statis pada permukaan sudu forward lengkung

\section{Kesimpulan}

Turbin dengan sudu backward lengkung mampu membangkitkan torsi yang lebih besar daripada turbin sudu forward lengkung untuk seluruh variasi kecepatan turbin yang dilakukan. Baik sudu backward lengkung maupun forward lengkung, nilai torsi semakin menurun seiring bertambahnya kecepatan putar turbin. Hal tersebut terjadi karena berkurangnya gaya reaksi akibat berkurangnya perbedaan kecepatan antara kecepatan rotasi air dengan rotasi turbin. Daya mekanik, yang merupakan perkalian torsi dan kecepatan rotasi turbin, nilainya tertinggi pada kecepatan putar turbin 120 rpm, yaitu pada sudu backward lengkung sebesar 2,34 W dan sudu forward lengkung sebesar 1,51 W. Penambahan kecepatan rotasi turbin mempengarui posisi permukaan bebas pada masing-masing kasus. Semakin tinggi kecepatan putar turbin, maka permukaan air pada bagian basin atas akan semakin naik karena gaya sentrifugal yang semakin tinggi. Terjadi transfer momentum dari aliran vortex ke permukaan sudu turbin. Interaksi vortex dan sudu turbin, teramati menghasilkan kecepatan yang lebih tinggi pada sudu backward lengkung, yang juga teramati dari sisi kontur tekanan statis pada permukaan sudu backward lengkung mengalami pressure drop yang lebih tinggi daripada yang terjadi pada interkasi vortex dengan sudu forward lengkung. 
Didit Setyo Pamuji dkk /Jurnal Rekayasa Mesin

p-ISSN: 1411-6863, e-ISSN: 2540-7678

Vol.16|No.1|48-55|April|2021

\section{Ucapan terima kasih}

Penulis mengucapkan terimakasih kepada Deputi Bidang Penguatan Riset dan Pengembangan Kementrian Riset dan Teknologi / Badan Riset dan Inovasi Nasional atas pembiayaan penelitian ini pada tahun anggaran 2020.

\section{Daftar Pustaka}

[1] J. Hanafi and A. Riman, "Life cycle assessment of a mini hydro power plant in Indonesia: A case study in Karai River," Procedia CIRP, vol. 29, pp. 444-449, 2015.

[2] Erinofiardi et al., "A Review on Micro Hydropower in Indonesia," Energy Procedia, vol. 110, no. December 2016, pp. 316-321, 2017.

[3] P. K. Talukdar, V. Kulkarni, and U. K. Saha, "Field-testing of model helical-bladed hydrokinetic turbines for small-scale power generation,” Renew. Energy, vol. 127, pp. 158-167, 2018.

[4] P. Sritram and R. Suntivarakorn, "Comparative Study of Small Hydropower Turbine Efficiency at Low Head Water," Energy Procedia, vol. 138, pp. 646-650, 2017.

[5] O. B. Yaakob, Y. M. Ahmed, A. H. Elbatran, and H. M. Shabara, "A review on micro hydro gravitational vortex power and turbine systems," J. Teknol. (Sciences Eng., vol. 69, no. 7, pp. 1-7, 2014.

[6] S. Wanchat and R. Suntivarakorn, "Preliminary design of a vortex pool for electrical generation," Adv. Sci. Lett., vol. 13, no. January 2011, pp. 173-177, 2012.

[7] C. Power, A. McNabola, and P. Coughlan, "A Parametric Experimental Investigation of the Operating Conditions of Gravitational Vortex Hydropower (GVHP),” J. Clean Energy Technol., vol. 4, no. 2, pp. 112-119, 2015.

[8] S. Dhakal, S. Nakarmi, P. Pun, A. Bikram Thapa, and T. Ratna Bajracharya, "Development and testing of runner and conical basin for gravitational water vortex power plant,” J. Inst. Eng., vol. 10, no. 1, pp. 140-148, 2014.

[9] P. Sritram, W. Treedet, and R. Suntivarakorn, "Effect of turbine materials on power generation efficiency from free water vortex hydro power plant," IOP Conf. Ser. Mater. Sci. Eng., vol. 103, no. 1, 2015.

[10] C. B. Gheorghe-Marius MARIAN, Tudor SAJIN, Iulian FLORESCU, Dragos-Iulian NEDELCU, ConstantinNarcis OSTAHIE, "the Concept and Theoretical Study of Micro Hydropower Plant With Gravitational the Concept and Theoretical Study of Micro Hydropower Plant With Wit H Gravitational Vortex and," World Energy Syst. Conf., no. 3, pp. 219-226, 2012.

[11] S. Dhakal et al., "Comparison of cylindrical and conical basins with optimum position of runner: Gravitational water vortex power plant," Renew. Sustain. Energy Rev., vol. 48, no. August, pp. 662-669, 2015.

[12] R. Ullah, T. A. Cheema, A. S. Saleem, S. M. Ahmad, J. A. Chattha, and C. W. Park, "Preliminary experimental study on multi-stage gravitational water vortex turbine in a conical basin," Renew. Energy, vol. 145, pp. 25162529, 2020.

[13] Y. Nishi and T. Inagaki, "Performance and Flow Field of a Gravitation Vortex Type Water Turbine," Int. J. Rotating Mach., vol. 2017, 2017.

[14] H. M. Shabara, O. B. Yaakob, Y. M. Ahmed, A. H. Elbatran, and M. S. M. Faddir, "CFD validation for efficient gravitational vortex pool system,” J. Teknol., vol. 74, no. 5, pp. 97-100, 2015.

[15] Y. A. Cengel and J. M. Cimbala, Fluid Mechanics - Fundamentals and Applications 3rd Edition [Cengel and Cimbala-2014]. 2014. 